\title{
Assessment of Factors Affecting the Treatment Efficacy of Radioactive lodine (I-131) Therapy in Patients with Hyperthyroidism
}

\section{Özgün Araştırma Research Article}

\author{
Hipertiroidi Hastalarında Radyoaktif iyot (I-131) Tedavi \\ Başarısını Etkileyen Faktörlerin Değerlendirilmesi
}

Received/Geliş: 02.09.2019 Accepted/Kabul: 30.04 .2020

Published Online: 18.08 .2021

Ferhat Arık Tomarza Yaşar Karayel illçe Devlet Hastanesi 38900 Kayseri - Türkiye ferhatarik@gmail.com ORCID: 0000-0001-6929-4666

F. Gökay 0000-0003-1691-7940 Kayseri Şehir Hastanesi Kayseri, Türkiye

B. E. Arık 0000-0002-0898-1099 Erciyes Üniversitesi Tıp Fakültesi, Aile Hekimliği Anabilim Dalı, Kayseri, Türkiye

Cite as: Ark $F$, Gökay $F$, Ertürk Arik B. Assessment of factors affecting the treatment efficacy of radioactive iodine (I-131) therapy in patients with hyperthyroidism. Tepecik Eğit. ve patients with hyperthyroidism. Tepecik
Arasst. Hast. Dergisi. 2021;31(2):236-45.
Ferhat Arık $\odot$, Ferhat Gökay ${ }^{\oplus}$, Bade Ertürk Arık $\odot$

\begin{abstract}
Objective: Hyperthyroidism is an increase in hormone production in the thyroid gland and the exposure of tissues to the hormones of the thyroid glands in the circulation. The most common causes encountered are Graves' Disease, Toxic Multinodular Goiter and Toxic Adenoma. The purpose of radioactive iodine treatment is to make patients become euthyroid or hypothyroid. Despite adequate treatment, hyperthyroidism persists or reccurs in some patients. The aim of our study is to investigate the factors affecting the efficacy of radioactive iodine treatment in hyperthyroidism.

Methods: In this retrospective study, relevant clinical and laboratory data were recorded in database of Kayseri Training and Research Hospital, Endocrinology and Metabolism Diseases Outpatient Unit between 2013-2016. Results: A total of 79 cases including 17 (21\%) male, and 62 (79\%) female patients were enrolled in the study. There were 33 (42\%) Graves' disease 9 (11\%) Toxic Multinodular Goitre and 37 (47\%) Toxic Adenoma patients when grouped according to diagnoses. Mean age was $56.5 \pm 16,80$. Development of hypothyroidism or euthyroidism were accepted as efficient treatment, hyperthyroidism or recurrence were considered as treatment failure. In 71 (89\%) patients, treatment efficiently resulted in hypothyroidism or euthyroidism, whereas in 8 (11\%) patients, the treatment failed due to recurrence or persistent disease. Treatment was $100 \%$ effective in Toxic Multinodular Goitre and Toxic Adenoma groups, while it was effective in 75.7 of patients with Graves' Disease. Patients who did not use antithyroid drugs recovered faster than patients who did.

Conclusion: Radioactive iodine therapy is an efficient treatment in patients with hyperthyroidism. It was determined that $1 \mathrm{~mm}$ increase in nodule size decreased the treatment efficacy by 1.07 times $(p<0,05)$. However, there are many factors that affect the efficacy of this treatment. To elucidate these factors and improve clinical practice, prospective long-term studies providing more reliable data with larger samples needed.
\end{abstract}

Keywords: Hyperthyroidism, radioactive iodine therapy, methimazole, propylthiouracil, treatment efficacy

öz

Amaç: Hipertiroidi, tiroid bezinde hormon üretiminde bir artış ve dokuların dolaşımdaki tiroid bezlerinin hormonlarına maruz kalmasıdır. En sık karşılaşılan nedenler Graves Hastalığı, Toksik Multinodüler Guatr ve Toksik Adenomdur. Radyoaktif iyot tedavisinin amacı hastaları ötiroid veya hipotiroidi haline getirmektir. Yeterli tedaviye rağmen, hipertiroidi bazı hastalarda devam eder veya tekrar eder. Çalıșmamızın amacı hipertiroidide radyoaktif iyot tedavisinin etkinliğini etkileyen faktörleri araştırmaktır.

Yöntem: Bu retrospektif çalıșmada, 2013-2016 yılları arasında Kayseri Eğitim ve Araștırma Hastanesi Endokrinoloji ve Metabolizma Hastalıkları Polikliniğinde klinik ve laboratuvar verileri kaydedildi.

Bulgular: Calıșmaya toplam 79 hasta dahil edildi. Tanılara göre gruplandırıldığında 33 (\% 42) Graves, 9 (\% 11) Toksik Multinodüler Guatr ve 37 (\% 47) Toksik Adenom hastası vardı. Yaş ortalaması 56,5 \pm 16,80 idi. 17 hasta (\% 21) erkek, 62 hasta (\% 79) kadındı. Hipotiroidizm veya ötiroidi gelişimi etkin tedavi olarak kabul edildi, hipertiroidizm veya rekürrens tedavi başarısızlığı olarak kabul edildi. 71 hastada (\% 89) tedavi etkin şekilde hipotiroidizm veya ötiroidizm ile sonuçlandı, 8 hastada (\% 11) ise nüks veya kalıcı hastalık nedeniyle tedavi başarısız oldu. Toksik Multinodular Guatr ve Toksik Adenomda etkinlik oranı\% 100 iken Graves hastalarında etkinlik oranı 75.7 idi. Antitroid ilaç kullanmayan hastalar, antitroid ilaç kullanan hastalardan daha hızlı iyileşti. Nodül boyutundaki 1 mm'lik artışın tedavi etkinliğini 1,07 kat azalttığı tespit edildi $(p<0,05)$.

Sonuç: Radyoaktif iyot tedavisi hipertiroidi olan hastalarda etkili bir tedavidir. Nodül boyutundaki $1 \mathrm{~mm}$ 'lik artışın tedavi etkinliğini 1.07 kat azalttı̆̆ı tespit edildi $(p<0,05)$. Bununla birlikte, bu tedavinin etkinliğini etkileyen birçok faktör vardır. Bu faktörleri aydınlatmak ve Klinik Uygulamaları iyileştirmek için, daha büyük örneklerle daha güvenilir veriler sağlayan prospektif uzun vadeli çalıșmalar gereklidir.

Anahtar kelimeler: Hipertiroidi, radyoaktif iyot tedavisi, metimazol, propiltiourasil, tedavi etkinliği

(C) Telif hakkı TC. Sağlık Bakanlı̆ı İzmir Tepecik Eğit. ve Arastt. Hastanesi. Logos Tıp Yayınclık tarafindan yayınlanmaktadır.

Bu dergide yayınlanan bütün makaleler Creative Commons Atf-GayriTicari 4.0 Uluslararası Lisansı ile lisanslanmıştır.

(c) Copyright Association of Publication of the T.C. Ministry of Health İzmir Tepecik Education and Research Hospital.

This journal published by Logos Medical Publishing.

Licenced by Creative Commons Attribution-NonCommercial 4.0 International (CC BY) 


\section{INTRODUCTION}

'Thyrotoxicosis' is a general term that expresses the excess of thyroid hormone. Hyperthyroidism means specifically the excess of thyroid hormone due to increaased thyroid hormone production in thyroid gland $^{(1)}$.

Hyperthyroidism is an important public health problem that occurs more frequently in women than men. In a survey, which was conducted in the United States, the prevalence of hyperthyroidism was $1.3 \%$ and also the 12 -month- prevalence was $0.038 \%$ in women ${ }^{(2)}$. Hyperthyroidism is more common in the iodine-deficient areas, especially the elderly and the white race ${ }^{(2,3)}$.

In patients with hyperthyroidism, three common diseases of the thyroid gland were identified; Graves' Disease (GD), Toxic Multinodular Goiter (TMNG) and Toxic Adenoma (TA). The most common cause of hyperthyroidism is GD.

Treatment of hyperthyroidism includes also three options; antithyroid drugs (ATI), radioactive iodine therapy (RAI therapy) and surgical treatment ${ }^{(4)}$.

The most common ATIs preferred are methimazole (MMI) followed by propylthiouracil (PTU). Carbimazole must be metabolized to $\mathrm{MMI}$ in order to show its effect.

The indications of RAI therapy, in which radioactive lodine 131 (I-131) is used include GD, TA, TMNG and thyroid cancers. I-131 acts by spreading high energy beta rays, while beaming on the thyroid follicular cells with the beta $(\beta)$ rays which results in dimerization and destruction of DNA, ultimately leading to cellular dysfunction and cellular death. The goal is to ACHIEVE euthyroidism by destroying an adequate amount of thyroid tissue. Euthyroidism or hypothyroidism is considered as an efficient treatment response, while persistent hyperthyroidism and recurrence after a short-term recovery are considered to be treatment failures ${ }^{(5,6)}$. Absolute contrain- dications of treatment with RAI are pregnancy, breast-feeding and thyroid malignancy. Also, serious orbitopathy should be considered as a relative contraindication ${ }^{(7)}$.

The aim of this study is to evaluate the treatment efficacy of I-131 in patients with hyperthyroidism who were followed-up in our endocrinology outpatient clinic.

\section{MATERIAL and METHOD}

Patients diagnosed with hyperthyroidism and treated with RAI which were followed-up at least for 6 months in the Endocrinology and Metabolic Diseases Outpatient Clinic of Kayseri Training and Research Hospital between 2013 and 2016 were included in the study if clinical and laboratory data are available. Patients who had less than 6 months of follow-up and with unavailable laboratory data were excluded from the study.

A total of 79 patients who met the criteria for the present study were collected. The clinical and laboratory data of the included patients were examined retrospectively. Anamnesis and detailed physical examination records of the patients were evaluated as clinical data.

Patients were grouped as having normal or large thyroid gland volume according to their ultrasound examination results. The upper limit of the thyroid gland volume was accepted as $18 \mathrm{ml}$ in women and $25 \mathrm{ml}$ in men ${ }^{(8)}$. In the TA and TMNG patients, the largest diameter of the dominant nodule was accepted as the nodule size. The normal range for the technetium pertecnetate $(99 \mathrm{mTcO} 4)$ uptake value was assumed to range between $0.3 \%$ to $3 \%{ }^{(9,10)}$.

For the thyroid function tests, the values of the reference intervals of the Training and Research Hospital Biochemistry Laboratory were accepted as normal. The measurements of free T3 (fT3) and free T4 (fT4) were made by using immunometric methods. The reference ranges were $2.5-4.8 \mathrm{pg} / \mathrm{ml}$ for fT3 and 
0.54-1.24 ng/dl for fT4. The measurement of thyroid stimulant hormone (TSH) was performed by the IRMA (Immunoradiometric Assay) method, although the values were dependent on both the method and the reference population, the reference values were considered as ranging between 0.4 , and $5.6 \mathrm{mIU} / \mathrm{ml}$.

The emergence of euthyroidism and hypothyroidism after RAI treatment was considered as effective and adequate treatment. Recurrence and persistence of hyperthyroidism were considered treatment failures. In some of the analyzes, TMNG and TA were reduced to a single group and the patients were compared in terms of treatment efficiency as having GD and toxic nodular goitre.

Histogram, QQ graphs and Shapiro-Wilk test were used to analyse the data distribution. Homogeneity of variance was assessed by Levene test. Pearson chi-square analysis and Fisher exact tests are conducted for evaluating qualitative data. Two independent samples t-test, one-way analysis of variance, Mann-Whitney $\mathrm{U}$ test and Kruskal-Wallis $\mathrm{H}$ tests were used for quantitative data. Kaplan-Meier graphs were created to investigate the effects of clinical data on the duration of efficacy. Log-rank test was used to compare the Kaplan-Meier curves between groups. Single and multiple Cox regression analyzes were performed to determine how much clinical data contributed to the duration of efficacy. The variables that were significant in the single regression analysis were included in the multiple analysis, and the likelihood ratio statistics was applied to the forward-looking variable selection method and the independent factors on the duration of efficacy were determined. Findings of the Cox regression analysis were reported as hazard ratio and 95\% confidence interval. Data were analyzed by using IBM SPSS Statistics 22.0 (IBM SPSS Inc, USA) package program. The $p<0.05$ was considered statistically significant.

\section{RESULTS}

When the patients were grouped according to their diagnoses; 33 patients (42\%) had GD, 9 (11\%) had TMNG and 37 (47\%) had TA. Seventeen (21\%) male and 62 (79\%) female patients were included in the study. Patients with GD received at least 18 months of ATI treatment before RAI and did not have remission or recurrence.

Fifty-five (70\%) patients were non-smokers and 24 (30\%) were smokers. In all three groups, 56 (71\%) patients were present with a history of ATI use, and also 23 (29\%) patients had received RAl treatment without using ATI. Thirty five (48\%) patients were using propranolol. When thyroid volumes of patients were evaluated, thyroid hypertrophy was detected in 51 (64\%) patients, while 28 (35\%) patients had normal.-sized thyroids

The results showing the relationships among the parameters studied in diagnostic groups of GD, TMNG, TA are given in (Tables 1, and 2)

Results showing demographic, clinical and biochemical findings in patients with successful and unsuccessful treatment are given in Tables 3 and 4.

According to the multiple Cox regression analysis conducted in our study, the nodule size was found to be an independent factor in the treatment efficacy. In terms of treatment efficacy, each $1 \mathrm{~mm}$ increase in nodule size increased treatment efficacy by 1.07 times $(p<0,05)$.

\section{DISCUSSION}

The efficacy of RAl treatment in patients with hyperthyroidism has been known since the 1940s, and although treatment has been used for many years. Nevertheless, there has been no consensus among the factors affecting treatment efficacy and treatment. The results of RAI treatment were found to be different among the centers due to the use of specific protocols in the field of RAI application, the individualization of treatment indications and the change in the patient population. 
Table 1. Comparison of demographic and clinical findings between diagnostic groups.

\begin{tabular}{|c|c|c|c|c|c|}
\hline Variable & & $\begin{array}{c}\text { GD } \\
(n: 33)\end{array}$ & $\begin{array}{l}\text { TMNG } \\
(\mathrm{n}: 9)\end{array}$ & $\begin{array}{c}\mathrm{TA} \\
(\mathrm{n}: 37)\end{array}$ & $\mathbf{p}$ \\
\hline Gender & $\begin{array}{l}\text { Woman } \\
\text { Male }\end{array}$ & $\begin{array}{l}26(78.8 \%) \\
7(21.2 \%)\end{array}$ & $\begin{array}{c}7(77 \%) \\
2(22.2 \%)\end{array}$ & $\begin{array}{l}29(78.4 \%) \\
8(21.6 \%)\end{array}$ & 0.998 \\
\hline ATI use before RAI treatment & $\begin{array}{l}\text { Used } \\
\text { Did not used }\end{array}$ & $\begin{array}{c}30(94 \%) \\
2(6 \%)\end{array}$ & $\begin{array}{l}7(77.8 \%) \\
2(22.2 \%)\end{array}$ & $\begin{array}{l}19(51.4 \%) \\
18(48.6 \%)\end{array}$ & $<0.001$ \\
\hline MMI usebefore RAI treatment & $\begin{array}{l}\text { Used } \\
\text { Did not used }\end{array}$ & $\begin{array}{l}13(39.4 \%) \\
19(82.6 \%)\end{array}$ & $\begin{array}{c}4(44.4 \%) \\
2(40 \%)\end{array}$ & $\begin{array}{c}12(32.4 \%) \\
7(46.7 \%)\end{array}$ & 0.731 \\
\hline Thyroid volume & $\begin{array}{l}\text { Normal } \\
\text { Large }\end{array}$ & $\begin{array}{l}10(30.3 \%) \\
23(69.7 \%)\end{array}$ & $\begin{array}{l}3(33.3 \%) \\
6(66.7 \%)\end{array}$ & $\begin{array}{l}15(40.5 \%) \\
22(59.5 \%)\end{array}$ & 0.664 \\
\hline 1. Month ATI Use after RAI treatment & $\begin{array}{l}\text { Used } \\
\text { Did not used }\end{array}$ & $\begin{array}{c}27(81.8 \%) \\
6(18.2 \%)\end{array}$ & $\begin{array}{l}4(44.4 \%) \\
5(55.6 \%)\end{array}$ & $\begin{array}{l}15(40.5 \%) \\
22(59.5 \%)\end{array}$ & 0.001 \\
\hline
\end{tabular}

The relationship table of the parameters in diagnosis groups (GD: Graves' disease, TMNG: Toxic multinodular goiter, TA: Toxic adenoma). The data is expressed using $N(\%)$, mean \pm standard deviation or median at first and third quarter.

Table 2. Comparison of demographic, clinical and biochemical findings among diagnostic.

\begin{tabular}{|c|c|c|c|c|c|}
\hline \multirow[b]{2}{*}{ Variable } & \multirow[b]{2}{*}{ Years } & \multicolumn{3}{|c|}{ Diagnosıs GROUPS } & \multirow[b]{2}{*}{$\mathbf{p}$} \\
\hline & & $\begin{array}{c}\text { GD } \\
(n: 33)\end{array}$ & $\begin{array}{c}\text { TMNG } \\
(\mathrm{n}: 9)\end{array}$ & $\begin{array}{c}\text { TA } \\
(n: 37)\end{array}$ & \\
\hline Age & Months & $53.38 \pm 15.33^{\mathrm{a}}$ & $65.75 \pm 14.5^{b}$ & $60.32 \pm 12.24^{b}$ & 0.033 \\
\hline Duration of disease before RAI treatment & & $24.0(18.0-33.5)^{b}$ & $5.0(2-75.5)^{\mathrm{ab}}$ & $3.0(2.0-5.0)^{\mathrm{a}}$ & $<0.001$ \\
\hline TSH at the time of diagnosis & & $0.02(0.008-0.04)^{b}$ & $0.03(0.01-0.7)^{\mathrm{ab}}$ & $0.4(0.01-0.16)^{\mathrm{a}}$ & 0.035 \\
\hline FT4 at the time of diagnosis & & $2.0(1.60-2.70)^{\mathrm{b}}$ & $1.37(0.97-1.8)^{\mathrm{a}}$ & $1.18(0.9-1.77)^{\mathrm{a}}$ & $<0.001$ \\
\hline FT3 at the time of diagnosis & & $4.82(3.78-8.61)^{b}$ & $3.7(2.60-4.30)^{\mathrm{ab}}$ & $3.9(3.54-4.38)^{\mathrm{a}}$ & 0.05 \\
\hline 99mTcO4 uptake & & $7.0(4.10-23.4)^{\mathrm{b}}$ & $2.2(1.40-3.85) a$ & $2.6(1.80-4.60)^{\mathrm{a}}$ & 0.001 \\
\hline TSH before RAI treatment & & $0.13(0.02-0.87)$ & $0.25(0.02-1.68)$ & $0.25(0.07-0.52)$ & 0.675 \\
\hline fT4 before RAI treatment & & $0.96(0.71-1.33)$ & $0.80(0.66-0.99)$ & $0.86(2.80-3.61)$ & 0.121 \\
\hline fT3 before RAI treatment & & $3.21(2.93-4.84)$ & $2.80(2.39-3.64)$ & $3.09(2.80-3.61)$ & 0.106 \\
\hline Thyroid volume & $\mathrm{ml}$ & $29.6(15.8-40.5)$ & $24.4(17.3-56.2)$ & $28.7(16.4-36.9)$ & 0.994 \\
\hline Nodule size & $\mathrm{mm}$ & $\underline{-}$ & $19.5(13-24.4)$ & $25(16.2-28.7)$ & 0.409 \\
\hline RAI Dose & & $15(15-15)$ & $15(15-15)$ & $15(15-15)$ & 0.830 \\
\hline
\end{tabular}

The relationship table of the parameters in diagnosis groups (GD: Graves' disease, TMNG: Toxic multinodular goiter, TA: Toxic adenoma). The data is expressed using $N(\%)$, meantstandard deviation or median at first and third quarter. The different letters on the same line refer to the cross-group differences, the same letters, and the similarity between groups. Different letters on the same line indicate differences between groups, and the same letters indicate similarity between groups. 
Table 3. Comparison of demographic, clinical and biochemical findings with efficiency status.

\begin{tabular}{|c|c|c|c|c|}
\hline \multirow[b]{2}{*}{ Variable } & & \multicolumn{2}{|c|}{ GROUP } & \multirow[b]{2}{*}{$\mathbf{p}$} \\
\hline & & $\begin{array}{c}\text { Effficiently Treated } \\
\text { (Euthyroidism + Hypothyroidism) } \\
(\mathrm{n}: 71)\end{array}$ & $\begin{array}{l}\text { Treatment Failure } \\
\text { (Hyperthyroidism) } \\
(n: 8)\end{array}$ & \\
\hline Age & Years & $58.7 \pm 13.98$ & $51.6 \pm 16.06$ & 0.184 \\
\hline $\begin{array}{l}\text { Before the Rai treatment } \\
\text { Disease Duration }\end{array}$ & months & $5.0(2.0-22.0)$ & $17.0(12.0-25.5)$ & 0.057 \\
\hline Use of ATI before RAI treatment & months & $4.0(0.0-18.0)$ & $16.0(10.0-23.5)$ & 0.015 \\
\hline $\begin{array}{l}\text { Diagnosis Instant } \\
\text { TSH }\end{array}$ & & $0.03(0.01-0.09)$ & $0.04(0.02-0.057)$ & 0.781 \\
\hline $\begin{array}{l}\text { Diagnosis Instant } \\
\text { fT4 }\end{array}$ & & $1.54(1.03-2.20)$ & $2.3(1.62-5.29)$ & 0.022 \\
\hline $\begin{array}{l}\text { Diagnosis Instant } \\
\text { fT3 }\end{array}$ & & $4.01(3.65-4.76)$ & $4.84(2.90-12.72)$ & 0.492 \\
\hline $\begin{array}{l}\text { Before Rai treatment } \\
\text { TSH }\end{array}$ & & $0.25(0.06-0.80)$ & $0.05(0.02-0.67)$ & 0.023 \\
\hline $\begin{array}{l}\text { Before RAltreatment } \\
\text { fT4 }\end{array}$ & & $0.87(0.72-1.07)$ & $1.09(0.78-1.91)$ & 0.139 \\
\hline $\begin{array}{l}\text { Before Rai treatment } \\
\text { fT3 }\end{array}$ & & $3.06(2.80-3.62)$ & $4.97(3.67-8.02)$ & 0.003 \\
\hline thyroid volume & $\mathrm{ml}$ & $23.4(15.4-35.0)$ & $43.9(30.4-48.2)$ & 0.033 \\
\hline${ }^{99} \mathrm{mTcO} 4$ & & $3.95(2.22-6.85)$ & $11.9(6.1-29.0)$ & 0.037 \\
\hline RAi Dozu & & $15.0(15.0-15.0)$ & $15.0(11.2-20.0)$ & 0.687 \\
\hline
\end{tabular}

Groups (efficiently treated: patients with euthyroidism or hyperthyroidism after the RAl treatment; treatment failure: persistant hyperthyroidism or recurrence after RAI therapy). The data is expressed using $N(\%)$, mean \pm standard deviation or median at first and third quarter.

Radioactive iodine therapy is the most commonly used method for treating GD in USA and Canada. For the treatment options of GD, long-term ATI is first tried out, and after the failure or development of recurrence, RAI treatment is planned for the eligible patients. In our study, the majority of 79 patients who received RAl treatment were TA and TMNG patients. The reason for the lower number of GD patients in our study was the use of ATI as a treatment priority in these patients.

Most (89\%) of all patients were effectively treated with an average treatment dose of $15.6 \mathrm{mCi}$ and evaluated after a 9.8 months of follow-up period. In our study, we assessed the efficacy of treatment according to subgroups. Our treatment efficacy rates after RAI were $76 \%$ in the GD group at $9.2^{\text {th }}$ and $100 \%$ in the TMNG at $4.2^{\text {th }}$ months. Efficacy rates of RAI treatment in retrospective studies performed in large series of patients with hyperthroidism in the literature have changed between $73-93 \%$, when evaluated independently of variables of dose and evaluation period ${ }^{(13)}$. In a study by Alexander et al ${ }^{(11)}, 75 \%$ of patients achieved treatment success after RAl treatment, while $25 \%$ had recurrence. In the study conducted by Knapska-Kucharska et al., RAI treatment of 133 (26.6\%) patients was unsuccessful, while success was achieved in the treatment of 367 (73.4\%) patients ${ }^{(12)}$. In the same studies, the treatment efficacy rates for GD, and TMNG were 67,5\%-89\%, and 70-96\%, respectively . Compared to the literature, our treatment efficacy rate in $\mathrm{GD}$ is seen to be compatible with the literature 
Table 3. Comparison of demographic, clinical and biochemical findings with efficiency status.

\begin{tabular}{|c|c|c|c|}
\hline \multirow[b]{2}{*}{ Variable } & \multicolumn{2}{|c|}{ GROUP } & \multirow[b]{2}{*}{$\mathbf{p}$} \\
\hline & $\begin{array}{c}\text { Effficiently Treated } \\
\text { (Euthyroidism + Hypothyroidism) } \\
\text { (n:71) }\end{array}$ & $\begin{array}{c}\text { Treatment Failure } \\
\text { (Hyperthyroidism) } \\
\text { (n:8) }\end{array}$ & \\
\hline $\begin{array}{l}\text { Significant Hyperthyroidism } \\
\text { Subclinical hyperthyroidism }\end{array}$ & $\begin{array}{l}48(85,7) \\
23(100)\end{array}$ & $\begin{array}{c}8(14,3) \\
0(0)\end{array}$ & 0,054 \\
\hline $\begin{array}{l}\text { Smoking } \\
\text { Non-smoking }\end{array}$ & $\begin{array}{l}21(87,5) \\
50(90,9)\end{array}$ & $\begin{array}{l}3(12,5) \\
5(9,1)\end{array}$ & 0,693 \\
\hline $\begin{array}{l}\text { Woman } \\
\text { Male }\end{array}$ & $\begin{array}{l}55(88,7) \\
16(94,1)\end{array}$ & $\begin{array}{l}7(11,3) \\
1(5,9)\end{array}$ & 0,450 \\
\hline $\begin{array}{l}\text { GD } \\
\text { TMNG } \\
\text { TA }\end{array}$ & $\begin{array}{c}25(75,7) \\
9(100) \\
37(100)\end{array}$ & $\begin{array}{l}8(24,3) \\
0(0) \\
0(0)\end{array}$ & 0,02 \\
\hline $\begin{array}{l}\text { Before RAI treatment } \\
\text { Using ATI }\end{array}$ & $50(86,2)$ & $8(13,8)$ & \\
\hline $\begin{array}{l}\text { Before RAI treatment } \\
\text { Not using ATI }\end{array}$ & $23(100)$ & $0(0)$ & 年 \\
\hline $\begin{array}{l}\text { Before RAI treatment } \\
\text { Using } \mathrm{MMI}\end{array}$ & $26(89,6)$ & $3(10,4)$ & \\
\hline $\begin{array}{l}\text { Before RAI treatment } \\
\text { Not using MMI }\end{array}$ & $45(90)$ & $5(10)$ & \\
\hline $\begin{array}{l}\text { Before RAI treatment } \\
\text { Using PTU }\end{array}$ & $21(91,3)$ & $2(8,7)$ & \\
\hline $\begin{array}{l}\text { Before RAl treatment } \\
\text { Not using PTU }\end{array}$ & $50(89,2)$ & $6(10,8)$ & \\
\hline $\begin{array}{l}\text { Before RAI treatment } \\
\text { Using } \mathrm{MMI}+\mathrm{PTU}\end{array}$ & $1(33)$ & $3(67)$ & \\
\hline $\begin{array}{l}\text { Before RAI treatment } \\
\text { Not using } \mathrm{MMI}+\text { PTU }\end{array}$ & $70(93,3)$ & $5(6,7)$ & \\
\hline Before RAI treatment using propranolol & $33(86,8)$ & $5(13,2)$ & \\
\hline Before RAI treatment not using propranolol & $38(92,6)$ & $3(7,4)$ & \\
\hline $\begin{array}{l}\text { First month after RAI treatment } \\
\text { Using ATI }\end{array}$ & $38(82,6)$ & $8(17,4)$ & \\
\hline $\begin{array}{l}\text { First month after RAI treatment } \\
\text { Not using ATI }\end{array}$ & $33(100)$ & $0(0)$ & \\
\hline Normal thyroid gland volume & $28(100)$ & $0(0)$ & \\
\hline Large thyroid gland volume & $43(84,3)$ & $8(15,7)$ & \\
\hline $\begin{array}{l}{ }^{99} \mathrm{mTcO} 4 \text { uptake }<3 \\
{ }^{99} \mathrm{mTcO} 4 \text { uptake }>3\end{array}$ & $\begin{array}{l}14(93,3) \\
22(78,5)\end{array}$ & $\begin{array}{l}1(6,7) \\
6(21,5)\end{array}$ & 0,391 \\
\hline
\end{tabular}

The data was expressed as $N(\%)$.

data, while our RAl treatment is apparently more successful in the TA and TMNG. This data may be related to the low number of patients.
In our study, the relationship between the size of the thyroid gland and the treatment efficacy was consistent with the literature. Furthermore in a 12-month 
Table 5. The percentage of efficient treatment in diagnostic groups after RAI administration according to months.

\begin{tabular}{lcccc}
\hline & & \multicolumn{3}{c}{ Diagnosis GROUPS } \\
\cline { 3 - 5 } Diagnosis & Hyperthyroidism & GD & TMNG & TA \\
\hline 1. Month & $\% 16$ & $\% 10$ & $\% 33$ & $\% 25$ \\
3. Month & $\% 45$ & $\% 28$ & $\% 86$ & $\% 60$ \\
6. Month & $\% 80$ & $\% 69$ & $\% 100$ & $\% 87$ \\
\hline
\end{tabular}

Hyperthyroidism includes all of the GD + TMNG + TA diagnostic groups.

Table 6. Single and multiple Cox regression of table factors affecting the efficacy.

\begin{tabular}{|c|c|c|c|c|c|}
\hline \multirow[b]{2}{*}{ Variable } & & \multicolumn{4}{|c|}{ GROUP } \\
\hline & & $\begin{array}{c}\text { Single } \\
\text { HO }(95 \% \mathrm{Cl})\end{array}$ & p & $\begin{array}{c}\text { MULTIPLE } \\
\text { HO }(95 \% \mathrm{Cl})\end{array}$ & $\mathbf{p}$ \\
\hline Nodule Size & $\mathrm{mm}$ & $1.04(1.01-1.07)$ & 0.006 & $1,07(1,02-1,12)$ & 0,004 \\
\hline Age & & $1.01(0.99-1.02)$ & 0.359 & & \\
\hline Gender & $\begin{array}{l}\text { Woman } \\
\text { Male }\end{array}$ & $\begin{array}{c}1 \\
1.09(0.62-1.91)\end{array}$ & 0.751 & & \\
\hline Diagnosis group & $\begin{array}{l}\text { GD } \\
\text { TMNG } \\
\text { TA }\end{array}$ & $\begin{array}{c}1 \\
4.2 \\
2.43\end{array}$ & $\begin{array}{c}<0.001 \\
0.001\end{array}$ & & \\
\hline $\begin{array}{l}\text { Mean } \\
\text { Disease Duration }\end{array}$ & months & $0.99(0.98-1.0))$ & 0.634 & & \\
\hline Before RAI treatment ATI use & $\begin{array}{l}\text { Do not use } \\
\text { Uses }\end{array}$ & $\begin{array}{c}1 \\
0.42(0.25-0.71)\end{array}$ & 0.001 & & \\
\hline $\begin{array}{l}\text { Diagnosis Instant } \\
\text { TSH }\end{array}$ & & $3.27(0.20-51.7)$ & 0.400 & & \\
\hline $\begin{array}{l}\text { Diagnosis Instant } \\
\text { T4 }\end{array}$ & & $0.71(0.55-0.71)$ & 0.007 & & \\
\hline $\begin{array}{l}\text { Diagnosis Instant } \\
\text { T3 }\end{array}$ & & $0.95(0.87-1.03)$ & 0.277 & & \\
\hline Tsh before Rai treatment & & $1.09(0.92-1.30)$ & 0.293 & & \\
\hline T4 before Rai treatment & & $0.53(0.29-0.97)$ & 0.359 & & \\
\hline T3 before Rai treatment & & $0.86(0.72-1.04)$ & 0.12 & & \\
\hline Thyroid volume & $\mathrm{ml}$ & $1.0(0.99-1.0)$ & 0.543 & & \\
\hline Thyroid volume & $\begin{array}{l}\text { Normal } \\
\text { Large }\end{array}$ & $\frac{1}{0.92(0.56-1.50)}$ & 0.750 & & \\
\hline RAI Dose & & $1.0(0.92-1.09)$ & 0.95 & & \\
\hline Cigarette & $\begin{array}{l}\text { Uses } \\
\text { Do not use }\end{array}$ & $\begin{array}{c}1 \\
1.01(0.61-1.69)\end{array}$ & 0.963 & & \\
\hline Cigarette & months & $1.0(0.99-1.0)$ & 0.628 & & \\
\hline 99mTcO4 uptake & & $0.94(0.90-0.99)$ & 0.031 & & \\
\hline
\end{tabular}

Evaluation of parameters with single and multiple Cox regression analysis. (HR: Hazard Ratio, Cl: Expressed using Confidence Interval) 
study of Chiovato L. et al., patients with hypothyroidism had significantly lower thyroid volumes ${ }^{(14)}$. In patients with normal thyroid gland size, treatment efficacy was found to be significantly higher than those with thyroid hypertrophy $(p<0.05)^{(15)}$.

In our study, there was no statistically significant difference between gender and treatment efficacy $(p<0.05)$. In our study, no statistically significant difference was found between gender and treatment success status $(p<0.05)$. There is no common consensus on the success of treatment and the gender factor, there are publications demonstrating that the treatment is more successful in women which indicates that it is ineffective or that gender does not affect treatment success rates ${ }^{(16-18)}$.

In our study, it was found that the low level of fT4 at the time of diagnosis, low fT3 concentration before RAI treatment and low levels of TSH were associated with the treatment efficacy $(p<0.05)$. In our study, compared to the treatment success rates of patients with hyperthyroidism and subclinical hyperthyroidism, the treatment success rate was higher in patients with subclinical hyperthyroidism than in patients with hyperthyroidism, with a statistically significant difference between both groups ( $p=0.054)$.

There are many studies related to thyroid function tests at the time of diagnosis and before the procedure. Studies have yielded different outcomes. It is thought that the outcomes may differ according to RAI's dose used in centers, age groups, diagnostic groups and the treatment efficacy of T4 and T3 impairment before RAI treatment. In another study, it was also reported that the high level of fT4, which was observed at the time of diagnosis, decreased the treatment efficacy rates ${ }^{(16,19,20)}$. Pedersen et al. reported that TSH levels were relatively higher in patients who were successfully treated ${ }^{(21)}$. In some studies, ie. in the study of Santos RB et al. ${ }^{(23)}$ it has been shown that thyroid hormone levels are not associated with the treatment efficacy ${ }^{(22)}$. TSH levels were not associated with treatment success.
Many different results have been obtained in studies investigating the relationship between radioactive iodine therapy and the use of ATI. In some studies, it has been reported that the use of ATI does not affect treatment efficacy, while in some studies using medication before or after treatment has been reported to reduce the efficacy of treatment (24-26). There are studies showing that the use of ATI affects the chances of treatment success according to the type of diagnosis. Körber et al. ${ }^{(27)}$ reported that use of antithyroid drugs did not change the treatment success rate in GD, but decreased the success of the treatment in patients diagnosed with TA or TMNG. In our study, it was found that treatment efficacy was lower in patients with increased duration of ATI used before RAl treatment $(p<0.05)$, besides, we found that using PTU or MMI before the treatment of RAI did not affect the treatment success and thus using $\mathrm{PTU}+\mathrm{MMI}$ adversely affected the treatment was statistically significant $(p<0.05)$. Failure in both PTU and MMI treatment is thought to be due to the high activity of the disease. Treatment failure was associated with highly active disease in the drug users, but the number of patients limited the validity of the comments about the outcome.

In our study, there was a statistically significant difference between the duration of disease and treatment failure before RAl treatment $(p=0.057)$. The longer the period, the lower the treatment efficacy. The majority of patients with long-term follow-up had GD.

In our study, an inverse correlation was found between thyroid uptake of $99 \mathrm{mTcO} 4$ and treatment success rates. While the treatment success of 3.95 (2.22-6.85) patients with $99 \mathrm{mTcO} 4$ uptake low was high, the success of treatment with low levels of 99mTcO4 uptake was $11.9(6.1-29.0)(p<0.05)$. In the literature, similar to our study, there are studies showing that $99 \mathrm{mTcO} 4$ uptake is inversely correlated with RAl therapy ${ }^{(28,29)}$. Moura-Neto A et al. reported, on 87 patients, could not find any relation between $99 \mathrm{mTcO} 4$ uptake and treatment efficacy (30). Compared to the literature, it is seen that our results 
are parallel with researchers defending the relationship between low uptake and high therapeutic efficacy.

There was no statistically significant difference in the treatment efficacy between non-smokers and smokers $(p>0.05)$.

When the percentage of efficacy is examined according to the months of RAl treatment, in patient groups with hyperthyroidism, the highest recovery is 9.8 months. A $90 \%$ recovery rate was detected per month. Despite a significant decrease in the later months of treatment, the recovery process continues. The earliest improvement was found in the TMNG group and the latest recovery was determined at GD when the hyperthyroidism subgroups were observed.

Single and multiple Cox Regression analysis were applied to the patient data and the effects of the variables on the treatment efficacy were investigated. The least treatment efficacy was achieved in GD and in TMNG, treatment efficacy rates were 4.2 times higher compared to GD.

At the time of diagnosis of hyperthyroidism patients, each $1 \mathrm{ng} / \mathrm{dl}$ increase in the fT4 value decreased the treatment efficacy by 1.42 times $(p<0.05)$. Every 1 $\mathrm{mm}$ increase in the size of the nodule decreased the treatment efficacy by 1.04 times in single Cox regression analysis and 1.07 times in multiple Cox regression analysis. The increase in the size of the nodule was thought to reduce the treatment efficacy due to increase in hormone production.

\section{CONCLUSIONS}

In this study, it has been shown that RAI treatment has been successfully used in hyperthyroidism (GD, TMNG, TA). In our study, antithyroid medication was used for a short term before RAI treatment; fT4 was lower at the time of diagnosis. Before treatment with RAI fT3 was lower, TSH was higher than their normal levels, thyroid volume was not increased.
Besides, active thyroid nodules were small in size and treatment efficacy demonstrated a positive correlation with these parameters. Age, gender, duration of the disease before RAl treatment, the use of PTU or MMI prior to RAI treatment, TSH, fT3 level, RAI dose and cigarette smoking at the time of diagnosis were not related to treatment efficacy ( $p>0.05$ ). However, in order to clarify this issue, planning longterm prospective investigations with more cases will provide more reliable data that can be used in clinical practice.

Ethics Committee Approval: Kayseri Training and Research Hospital Education Planning and Coordination Board Meeting approval was obtained (18.05.2016/53).

Conflict of Interest: The authors declare that they have no conflict of interest.

Funding: The authors received no financial support for the research, authorship, and or publication of this article.

Informed Consent: Informed consent was obtained.

\section{REFERENCES}

1. Akarsu E AF, Altay M et.al. Tirotoksikoz ve Hipertiroidi. Türkiye Endokrinoloji ve Metabolizma Derneği, tiroid hastalıkları tanı ve tedavi klavuzu. 2019:54-67.

2. Golden SH, Robinson KA, Saldanha I, Anton B, Ladenson PW. Clinical review: Prevalence and incidence of endocrine and metabolic disorders in the United States: a comprehensive review. J Clin Endocrinol Metab. 2009;94(6):1853-78. [CrossRef]

3. Flynn RW, MacDonald TM, Morris AD, Jung RT, Leese GP. The thyroid epidemiology, audit, and research study: thyroid dysfunction in the general population. J Clin Endocrinol Metab. 2004;89(8):3879-84. [CrossRef]

4. Bahn Chair RS, Burch HB, Cooper DS, et al. Hyperthyroidism and other causes of thyrotoxicosis: management guidelines of the American Thyroid Association and American Association of Clinical Endocrinologists. Thyroid. 2011;21(6):593-646. [CrossRef]

5. Howarth D, Epstein M, Lan L, Tan P, Booker J. Determination of the optimal minimum radioiodine dose in patients with Graves' disease: a clinical outcome study. Eur J Nucl Med. 2001;28(10):1489-95. [CrossRef]

6. Sgouros G, Kolbert KS, Sheikh A, et al. Patient-specific dosimetry for 131l thyroid cancer therapy using 124I PET and 3-dimensional-internal dosimetry (3D-ID) software. J Nucl Med. 2004;45(8):1366-72.

7. Burch HB, Burman KD, Cooper DS. A 2011 survey of clinical practice patterns in the management of Graves' disease. J 
Clin Endocrinol Metab. 2012;97(12):4549-58. [CrossRef]

8. Gutekunst R, Becker W, Hehrmann R, Olbricht T, Pfannenstiel P. [Ultrasonic diagnosis of the thyroid gland]. Dtsch Med Wochenschr. 1988;113(27):1109-12. [CrossRef]

9. Maisey MN, Natarajan TK, Hurley PJ, Wagner HN, Jr. Validation of a rapid computerized method of measuring $99 \mathrm{mTc}$ pertechnetate uptake for routine assessment of thyroid structure and function. J Clin Endocrinol Metab. 1973;36(2):317-22. [CrossRef]

10. Schneider PB. Simple, rapid thyroid function testing with 99mTc-pertechnetate thyroid uptake ratio and neck/thigh ratio. AJR Am J Roentgenol. 1979;132(2):249-53. [CrossRef]

11. Alexander EK, Larsen PR. High dose of (131)I therapy for the treatment of hyperthyroidism caused by Graves' disease. J Clin Endocrinol Metab. 2002;87(3):1073-7. [CrossRef]

12. Knapska-Kucharska M, Oszukowska L, Lewinski A. Analysis of demographic and clinical factors affecting the outcome of radioiodine therapy in patients with hyperthyroidism. Arch Med Sci. 2010;6(4):611-6. [CrossRef]

13. Schiavo M, Bagnara MC, Camerieri L, et al. Clinical efficacy of radioiodine therapy in multinodular toxic goiter, applying an implemented dose calculation algorithm. Endocrine. 2015;48(3):902-8. [CrossRef]

14. Chiovato $L$, Fiore $E$, Vitti $P$, et al. Outcome of thyroid function in Graves' patients treated with radioiodine: role of thyroidstimulating and thyrotropin-blocking antibodies and of radioiodine-induced thyroid damage. J Clin Endocrinol Metab. 1998;83(1):40-6. [CrossRef]

15. Pfeilschifter J, Elser H, Haufe S, Ziegler R, Georgi P. [Impact of pretreatment variables on the outcome of standardized 131I therapy with 150 Gray in Graves' disease]. Nuklearmedizin. 1997;36(3):81-6. [CrossRef]

16. Boelaert K, Syed AA, Manji N, et al. Prediction of cure and risk of hypothyroidism in patients receiving 131 l for hyperthyroidism. Clin Endocrinol (Oxf). 2009;70(1):129-38. [CrossRef]

17. Allahabadia A, Daykin J, Sheppard MC, Gough SC, Franklyn JA. Radioiodine treatment of hyperthyroidism-prognostic factors for outcome. J Clin Endocrinol Metab. 2001;86(8):3611-7. [CrossRef]

18. Ahmad AM, Ahmad M, Young ET. Objective estimates of the probability of developing hypothyroidism following radioactive iodine treatment of thyrotoxicosis. Eur J Endocrinol.
2002;146(6):767-75. [CrossRef]

19. DeGroot LJ, Mangklabruks A, McCormick M. Comparison of RA 131I treatment protocols for Graves' disease. J Endocrinol Invest. 1990;13(2):111-8. [CrossRef]

20. Gomez Arnaiz N, Gomez Saez JM, Orti Llaveria A, et al. [Results of treatment of Graves-Basedow disease with 131I at low calculated doses]. Rev Clin Esp. 1998;198(2):57-60.

21. Pedersen-Bjergaard U, Kirkegaard C. Serum TSH and the response to radioiodine treatment of toxic multinodular goitre. Eur J Endocrinol. 1997;137(4):365-9. [CrossRef]

22. Santos RB, Romaldini JH, Ward LS. Propylthiouracil reduces the effectiveness of radioiodine treatment in hyperthyroid patients with Graves' disease. Thyroid. 2004;14(7):525-30. [CrossRef]

23. Sanyal D, Mukhhopadhyay P, Pandit K, et al. Early treatment with low fixed dose $(5 \mathrm{mCi})$ radioiodine therapy is effective in Indian subjects with Graves' disease. J Indian Med Assoc. 2008;106(6):360-1, 72.

24. Sridama V, McCormick M, Kaplan EL, Fauchet R, DeGroot LJ. Long-term follow-up study of compensated low-dose 131। therapy for Graves' disease. N Engl J Med. 1984;311(7):42632. [CrossRef]

25. Bonnema SJ, Bartalena L, Toft AD, Hegedus L. Controversies in radioiodine therapy: relation to ophthalmopathy, the possible radioprotective effect of antithyroid drugs, and use in large goitres. Eur J Endocrinol. 2002;147(1):1-11. [CrossRef]

26. Weetman AP. Radioiodine treatment for benign thyroid diseases. Clin Endocrinol (Oxf). 2007;66(6):757-64. [CrossRef]

27. Walter MA, Briel M, Christ-Crain M, et al. Effects of antithyroid drugs on radioiodine treatment: systematic review and meta-analysis of randomised controlled trials. BMJ. 2007;334(7592):514. [CrossRef]

28. Dige-Petersen $\mathrm{H}$, Kroon S, Vadstrup S, Andersen ML, RoyPoulsen NO. A comparison of 99Tc and 123 I scintigraphy in nodular thyroid disorders. Eur J Nucl Med. 1978;3(1):1-4. [CrossRef]

29. Hou H, Hu S, Fan R, et al Prognostic value of $(99 \mathrm{~m})$ Tc-pertechnetate thyroid scintigraphy in radioiodine therapy in a cohort of Chinese Graves' disease patients: a pilot clinical study. Biomed Res Int. 2015;2015:974689. [CrossRef]

30. Moura-Neto A, Mosci C, Santos AO, et al. Predictive factors of failure in a fixed $15 \mathrm{mCi} 131 \mathrm{l}$-iodide therapy for Graves' disease. Clin Nucl Med. 2012;37(6):550-4. [CrossRef] 